\title{
A Postcritical Poetics? Transtemporal Encounters in Defunct Soviet Barracks in Works by Ulrike Almut Sandig and Clemens Meyer
}

Tom Smith, University of St Andrews

This article argues that Ulrike Almut Sandig's poetry models what might be termed a 'postcritical poetics', expanding on Rita Felski's idea of 'postcritical reading' to reveal strategies for a postcritical writing. In Sandig's earlier poems, particularly 'russenwald' and 'gardinen' (2007), she evokes encounters on and around former Soviet military installations. The poems assume a postcritical stance to the past and in turn prompt a postcritical reading. Using theories by Felski and José Esteban Muñoz, I argue that Sandig stages fleeting interpersonal encounters based on openness and fascination, which work against the backdrop of past and present violence in both works. Sandig's encounters suggest how everyday interactions can articulate dissatisfaction with a difficult present and look towards possible ethical relations in the future. Sandig's writing further suggests productive ways of reading other contemporary writing, which I demonstrate using Clemens Meyer's short narrative 'Glasscherben im Objekt 95' (2017), which also depicts a transtemporal encounter on a defunct Soviet military installation.

Keywords: time; encounter; postcritical; GDR; Soviet; military; ethics; poetics; contemporary; future

The image of defunct or derelict Soviet military installations features with remarkable prominence in German literature since the withdrawal of Soviet troops in 1994. From Angela Krauß’s Die Überfliegerin (1995) and Feridun Zaimoglu's German Amok (2002) to Uwe Tellkamp's Der Turm (2008), Russian soldiers and the spaces they once occupied recur in a wide range of texts. ${ }^{1}$ The importance of representations of Soviet military figures and spaces for reimagining social relations in contemporary German literature has received only sparse critical attention. Scholars have associated depictions of the Soviet military presence in Germany with a post-imperial project, with a haunting of the present by the past, or with post-1990 freedom and renewal. ${ }^{2}$ However, the work of Ulrike Almut

${ }^{1}$ Angela Krauß, Die Überfliegerin. Erzählung (Frankfurt am Main: Suhrkamp, 1995); Feridun Zaimoglu, German Amok. Roman (Frankfurt am Main: Fischer, 2002); Uwe Tellkamp, Der Turm. Geschichte aus einem versunkenen Land (Frankfurt am Main: Suhrkamp, 2008).

2 E.g. Julia Hell, 'Demolition Artists: Icono-Graphy, Tanks, and Scenarios of (Post-)Communist Subjectivity in Works by Neo Rauch, Heiner Müller, Durs Grünbein, and Uwe Tellkamp', 
Sandig suggests an interpretation that moves beyond backward-looking melancholy or triumphant celebration of post-socialist individualism. Through Sandig's work runs the motif of what she calls the 'russenwald', a space in which she depicts interpersonal encounters between Soviet soldiers and GDR citizens. ${ }^{3}$ Although Sandig does not eclipse the abuses and mistrust that dominated relations between GDR and Soviet citizens, fleeting, even imagined, encounters in her poetry gesture to the productive power of imagination and fascination in addressing difficult and troubling subject matter. Sandig's reimagining of Soviet-German relations resonates with and illuminates that of other contemporary writers, including Clemens Meyer, Antje Rávic Strubel, Kerstin Młynkec and Christoph Brumme. By attending closely to past encounters, Sandig's writing sets them against our present and suggests their future potential, pointing to forms of interpersonal relations based less on power and domination and more on care, intimacy and openness.

Sandig enacts what I will call a 'postcritical poetics', drawing on Rita Felski's discussion of the limitations of critique as an academic style. Felski advocates close attention and receptivity to the complexities and ambiguities of literary works. In The Limits of Critique (2015), she calls for analyses to engage in a reciprocal exchange with literary objects: 'works of art are not just objects to be interpreted; they also serve as frameworks and

Germanic Review, 89 (2014), 131-70; Julia Klassen, “"Do You Actually Love the Russians?": The Concept of "Total Love" as Narrative Strategy in Angela Krauß's Die Überfliegerin (1995)', Women in German Yearbook, 28 (2012), 23-41.

${ }^{3}$ See 'Gegen das Verschwinden', in Buch gegen das Verschwinden (Frankfurt am Main: Schöffling, 2015), pp. 9-42; and Peter Thompson's new translation in this volume. See also 'Im Schneekugelwald', in ich bin ein Feld voller Raps verstecke die Rehe und leuchte wie dreizehn Ölgemälde übereinandergelegt (Frankfurt am Main: Schöffling, 2016), p. 39; and 'Mein Löffel, mein Fluss, mein Pfefferminzsprech' in this volume. 
guides to interpretation'. ${ }^{4}$ By reading Sandig's poems 'russenwald' and 'gardinen' (2007), I suggest viewing her poetry as a form of postcritical writing. ${ }^{5}$ Expanding on Felski's work in this way, I explore how such writing can enact a postcritical encounter with the past. Rather than allowing past experiences to be interpreted in line with present assumptions or critical orthodoxies, Sandig's writing stages an openness to the complexity and diversity of experiences and to the power of imagination to propose more ethical modes of interpersonal and transtemporal relations. I go on to read Clemens Meyer's short narrative, 'Glasscherben im Objekt 95' (2017), in light of Sandig's poetry, as an example of how such an approach might be productive across a range of contemporary literature. ${ }^{6}$ Sandig's writing illuminates Meyer's prose, and gives concrete form to Felski's theoretical observations, while always exploring the political difficulties and future potential of such a poetics.

Sandig creates transtemporal encounters that stage more attentive and receptive ways of building relationships in an imagined future, and her use of Soviet military spaces forces us to consider the political implications of a postcritical approach. Intimate depictions of encounters in her poetry use the abuses of the past to imagine a more ethical future. Her writing in these early poems combines an often playful and associative tone with a lyric subject that often assumes a child's perspective. Her depictions of the 'russenwald' present in stark terms a constant threat of violence both by and towards Soviet soldiers. Yet her poems present only an enigmatic impression, often accompanied by a sense of

\footnotetext{
${ }^{4}$ Rita Felski, The Limits of Critique (Chicago: University of Chicago Press, 2015), p. 168.

${ }^{5}$ Ulrike Almut Sandig, Streumen. Gedichte (Leipzig: Connewitzer Verlagsbuchhandlung Peter Hinke, 2007), pp. 16 and 17.

${ }^{6}$ Clemens Meyer, 'Glasscherben im Objekt 95', in Die stillen Trabanten: Erzählungen (Frankfurt am Main: Fischer, 2017), pp. 10-36.
} 
disorientation, caused by the limited understanding of the children's voices she constructs. Their limited perspectives enact not only a failure to understand, but a refusal of the potentially violent scenes they witness, lending Sandig's postcritical approach a quiet political force. ${ }^{7}$ Her poems never lose sight of the atrocities of Soviet imperialism: they force readers or listeners to engage in careful, active interpretations and to confront the violence that the poem presents in such a stark way. By allowing interpersonal encounters to resonate across time, moreover, these texts suggest ways of looking forwards to a future based on dynamic, interpersonal connections that eschew a complacent or exclusionary us-and-them mentality. These futures may remain imaginary, but I will suggest that work on utopia and the everyday by the queer theorist José Muñoz allows us to read such literary experiments as performative assertions of the value of hope, change and possibility as ways of combatting an oppressive present. $^{8}$

The Red Army was stationed in East Germany continuously from the post-war occupation until the final withdrawal in 1994. The Soviet Military Administration (SMAD) was instrumental in establishing socialism in the GDR, including developing surveillance and police networks that would shape GDR citizens' lives and relationships for four decades. ${ }^{9}$ After the uprisings in 1953, which included localized attacks on the Gesellschaft für Deutsch-Sowjetische Freundschaft (DSF), SMAD relinquished control to give more legitimacy to the ruling Sozialistische Einheitspartei Deutschlands (SED). However, the

\footnotetext{
${ }^{7}$ For full discussion of Sandig's use of a child's perspective, see Heike Bartel's contribution to this volume.

${ }^{8}$ José Esteban Muñoz, Cruising Utopia: The Then and There of Queer Futurity (New York: New York University Press, 2009).

${ }^{9}$ For discussion of the Red Army's role in such policies, see Ilko-Sascha Kowalczuk and Stefan Wolle, Roter Stern über Deutschland. Sowjetische Truppen in der DDR, $2^{\text {nd }}$ edn (Berlin: Links, 2010), pp. 64-94.
} 
aftermath of 1953 also saw the establishment of a longer-term military presence, renamed the Gruppe der Sowjetischen Streitkräfte in Deutschland, which ensured that Soviet military support for the SED remained highly visible. ${ }^{10}$ Soviet troops and dependants remained the largest group of foreign nationals in the GDR, with a prominent presence in everyday life. ${ }^{11}$

Encounters between Germans and Soviets were generally restricted and ritualized, and representations in art, literature and film were an important means of stylizing these relations. In socialist realist works, archetypal Soviet soldiers often stand as an impersonal reminder of the example set by the Soviet 'Waffenbrüder'. In Horst Bastian's Gewalt und Zärtlichkeit novels (1974-1987), for example, the protagonist repeatedly draws inspiration for his socialist commitment from the statue in his village. ${ }^{12}$ Although statues were ubiquitous, 'really existing' Soviet soldiers were cloistered on secure bases, and Germans mostly encountered Russians during parades or official visits between youth groups or military units. ${ }^{13}$ János Veiczi's film Anflug Alpha 1 (1971), one of many collaborations between DEFA and the GDR military, shows a Russian general making just such a visit to a GDR air base. The film showcases the general's sympathetic but uncompromising fatherly demeanour with ordinary airmen. ${ }^{14}$ In line with Julia Hell's

${ }^{10}$ Ibid., pp. 106-7. On the DSF, see Jan C. Behrends, 'Sowjetische "Freunde" und fremde "Russen". Deutsch-Sowjetische Freundschaft zwischen Ideologie und Alltag (19491990)', in Fremde und Fremd-Sein in der DDR. Zu historischen Ursachen der Fremdenfeindlichkeit in Ostdeutschland, ed. by Jan C. Behrends, Thomas Lindenberger and Patrice G. Poutrus (Berlin: Metropol, 2003), pp. 75-98.

${ }^{11}$ Behrends, 'Sowjetische "Freunde", p. 75.

${ }^{12}$ Horst Bastian, Gewalt und Zärtlichkeit. Zweiter Roman (Berlin: Neues Leben, 1978), p. 14.

${ }^{13}$ Behrends, 'Sowjetische "Freunde”, pp. 78-79.

${ }^{14}$ Anflug Alpha 1, dir. by János Veiczi (DEFA, 1971). 
argument that antifascist narratives in the early GDR are constructed around paternal fantasies, these depictions of ritualized encounters in later decades continue to posit Soviet forces as mighty, benevolent father figures to eager GDR citizens. ${ }^{15}$

These ritualized official encounters were at odds with Germans' experiences of Soviet soldiers during and after the war, and the rumours, memories and family stories that circulated afterwards. The traumatic experiences of flight, expulsion and occupation between 1944 and 1949 rarely featured in published depictions of the Soviet advance, especially regarding the widespread use of sexual violence by Soviet troops and the experiences of those imprisoned in Soviet camps. As Bill Niven has argued, GDR culture associated the traumatic experiences of Germans so closely with their own guilt for the atrocities of the war that there was rarely a focus on aggression, violence and rape by Soviet soldiers. ${ }^{16}$ Birgit Dahlke has described how powerful feelings of shame and restrictions on what was deemed appropriate meant that such topics were circumscribed even in private. ${ }^{17}$ However, private discussions of these experiences continued to shape attitudes to occupying Soviet forces, and, as Niven points out, Christa Wolf's Kindheitsmuster (1976) was one prominent step in publicly addressing private experiences and memories of the Soviet occupation. ${ }^{18}$

\footnotetext{
${ }^{15}$ Julia Hell, Post-Fascist Fantasies: Psychoanalysis, History, and the Literature of East Germany (Durham, NC: Duke University Press, 1997). See also Bill Niven, Representations of Flight and Expulsion in East German Prose Works (Rochester, NY: Camden House, 2014), p. 32.

${ }^{16}$ Niven, Representations of Flight and Expulsion, p. 25.

${ }^{17}$ Birgit Dahlke, 'Tagebuch des Überlebens. Vergewaltigungen 1945 in ost- und westdeutschen Autobiographien', in Autobiography by Women in German, ed. by Mererid Puw Davies, Beth Linklater and Gisela Shaw (Oxford: Lang, 2000), pp. 195-212 (p. 197-98).

${ }^{18}$ Niven, Representations of Flight and Expulsion, pp. 39-42.
} 
From the 1960s, locals around Soviet bases increasingly encountered soldiers in informal settings, often against military regulations. These encounters did include criminality, drunkenness and occasional clashes, which Volker Koop has studied at length and which are better documented through conventional archive sources. ${ }^{19}$ As Jan Behrends has suggested, however, relatively little research has explored smaller scale, informal, personal encounters. Behrends argues that such interactions were often based around the exchange of goods in a society where necessities were scarce. ${ }^{20}$ However, literary depictions since 1990 have begun to depict Soviet military installations in imaginative, even surreal ways that go beyond relations of consumption. Sandig's poetry reconceptualizes the relationship between Soviet troops and Germans in the GDR by moving away from stereotypes of criminality, mistrust and antagonism, instead reimagining such encounters as friendly, caring and open-minded. While retaining reminders both of violence by and against Soviet soldiers and of the GDR's euphemistic and hegemonic rhetoric, Sandig enacts a performative refusal of stereotyping and of animosity between GDR and Soviet citizens. Her focus on moments of everyday interpersonal connection, and use of lyric subjects that show fascination with and even sympathy for Soviet soldiers, emerge prominently from the poems, even against the background threat of violence. She presents such encounters transcending their historical context, combining depictions of past events with the social concerns of the present, and looking to a future in which interpersonal relations are directed by openness rather than prejudice.

\footnotetext{
${ }^{19}$ Volker Koop, Zwischen Recht und Willkür. Die Rote Armee in Deutschland (Bonn: Bouvier, 1996).

${ }^{20}$ Behrends, 'Sowjetische "Freunde", p. 91.
} 
Sandig's poems 'russenwald' and 'gardinen' stage encounters between a child lyric subject and Soviet soldiers. 'russenwald', quoted here in full, constructs a child's perspective on the Soviet military installation from its opening:

russenwald war, worüber wir pfiffen, wohin wir nicht gingen, wo bündel aus licht in höhe der fichtkronen aufstiegen, rot, wo die asche von kippen und verbogener stahl die gräben bestrich an der grenze zum feld. am ortsrand bewegten sich tische und etwas weckte uns spät: es gab weiter hinten das ende vom weg.

betreten verboten vermintes gebiet / heide fallbaum lichtung moosrand / krater rotwild leere dörfer / backsteinhallen erika. es gab

panzerzüge, lkws, dunkelgrüne planen, drinnen standen vierzig mann, die schauten nach hinten in reihen heraus, alle köpfe rasiert. und es gab diesen einen, der vier stunden stillstand, im juli die hitze, auf der kreuzung allein, bis sie rollten in dreißig maschinen vorbei, und er hebt seine

rechte: militär vorfahrt / bis staub und das bellen von hunden und er sich nicht rührt / schmaler junge abendrot / mittelstreifen grün. es gab sie

schon immer und manchmal brachen sie latten vom zaun und schnitten den kohl auf und schossen die hennen. wer satt war, lief weiter zum fischteich, zur sonne, und tauschte mit kindern abzeichen ein, rot und sichel gegen freundschaft. wer das tat, kam lange nicht wieder. wir warteten umsonst. ${ }^{21}$

The 'russenwald' is from the first line a subject of fascination and rumour ('worüber wir pfiffen'), all the more so given its forbidden status. The lyric subject's impression of the military installation is mostly limited to visual observations that form dense associations, while leaving it to the reader to interpret the images. The effects of military manoeuvres are described without understanding their source: the red flares warning of a deserter or

\footnotetext{
${ }^{21}$ Sandig, Streumen, p. 16.
} 
a so-called Republikflucht are presented almost like fireworks above the treetops, while the tables, presumably shaking from the vibrations of heavy vehicles or artillery fire, take on a surreal capacity to move by themselves.

These enigmatic impressions are combined with wonder at the forbidden 'russenwald' and its foreign inhabitants. Sandig's use of rhythm creates fascination out of even the most threatening military images by developing acoustic as well as semantic resonances that stage the lyric subject's wide-eyed interest in the military installation. For example, the signpost in line eight, 'betreten verboten vermintes gebiet', is read as much for its dactylic rhythms and its patterns of ' $b$ ', ' $t$ ' and ' $v$ ' sounds as for its warning, as if deliberately refusing the exhortation to leave such memories in the past. The rhythm moves from these dactylic patterns to regular trochees with the slash in line eight and then becomes dactylic again at the comma in line twelve. The shifting but always regular rhythms in these three central strophes create a kaleidoscopic effect, constructing a mix of memories, impressions and imaginings. Sandig's patterning of stresses changes the poem's pace and interrupts a fluid reading, while repeatedly drawing readers or performers into the rhythms of these strophes and encouraging a similar fascination to that of the lyric subject.

The second and fourth strophes dispense with syntax and juxtapose military signs and slogans with observations of the landscape, causing the meanings of military language to merge with descriptions of the natural environment. Military buildings and signs are set amongst the flora ('moosrand', 'erika') and fauna ('rotwild') of the site, and many words assume multiple resonances. The 'fallbaum', occasionally used as a synonym for 'Schlagbaum' or barrier, is also a hunting term for a tree with a decoy to attract birds. The language of hunting reflects the enticing nature of the forbidden 'russenwald' to the lyric subject, as well as tying the military installation to its natural environment, called a wood, 
but here apparently more associated with heath and scrubland. The 'lichtung' in the woods resonates with the floodlights that surround military bases. Even the 'rotwild', a type of deer, suggests itself as an ironic reference to the soldiers, analogous to slang such as 'Rotlichtbestrahlung' for politics lessons in GDR schools and military units. The blurring of natural landscape and military installation is common in military writing, and representations of the GDR in particular: Holger Jancke's documentary Grenze (2003) or Urs Egger's film An die Grenze (2007) are examples contemporary with Streumen. ${ }^{22}$ Sandig's poetry, though, layers past and present landscapes over one another, with the 'leere dörfer' and images of overgrown scrubland suggesting that memories are prompted by remaining traces of Soviet military presence in the twenty-first-century landscape.

The uncertainty in the poem over where the past ends and the present begins is further intensified by its use of enjambment, which extends syntactical units over lines and even strophes. The three central strophes each end with a shift in tense between the preterite and the present. Yet these verbs are syntactically connected to the subsequent strophe, creating uncertainty about the temporality of the preceding lines and blurring past and present. The second strophe initially dispenses with verbs altogether, unsettling the temporality of the lyric subject's observations. It is never clear whether the 'krater rotwild | leere dörfer' or the 'heide | fallbaum lichtung moosrand' reflect the overgrown defences and empty structures roamed by animals after Soviet troops had withdrawn, or whether these observations are in the past suggested in the first strophe and reasserted by the unexpected 'es gab' in line ten. In line sixteen, the sudden shift to the present tense ('er

${ }^{22}$ Grenze: Lebensabschnitt Todesstreifen, dir. by Holger Jancke (Salzgeber, 2003); An die Grenze, dir. by Urs Egger (Colonia, 2007). See Rachel Woodward's discussion of rural landscapes in British military training materials, memoirs and television: 'Warrior Heroes and Little Green Men: Soldiers, Military Training, and the Construction of Rural Masculinities', Rural Sociology, 65 (2000), 640-57. 
hebt seine | rechte') interrupts the description of the soldier standing guard at the crossroads and affords his salute an unexpected immediacy. The lyric subject's fascination with the young soldier almost turns his salute into a greeting, an encounter which resonates in the poem's lyric present through the shift in tense.

In Sandig's poetry, such encounters are never consigned to the past, but rather burst into the lyric subject's present. The lasting effects of encounters such as with the soldier at the crossing suggest broader potential for an ethics based in apparently mundane interpersonal interactions. Muñoz's work on queer culture around Stonewall helps illuminate the political force behind Sandig's attention to everyday encounters. Muñoz's Cruising Utopia (2009) responds to the antisocial turn in queer studies, and theorists' calls for an antirelational politics of withdrawal and refusal. ${ }^{23}$ For Muñoz, a far greater, even utopian political force exists in everyday interactions: 'This quotidian example of the utopian can be glimpsed in utopian bonds, affiliations, designs, and gestures that exist within the present moment' ${ }^{24}$ The encounters Muñoz describes, whether in poetry, visual art or dance, gesture towards 'a way of being in the world that is glimpsed through reveries in a quotidian life that challenges the dominance of an affective world, a present, full of anxiousness and fear'. ${ }^{25}$ Sandig's use of a child's perspective in 'russenwald' poses just such a challenge. The lyric subject responds to the pervasive threat of violence contained in the surfeit of military symbolism in the poem not with more fear, but with fascination. Such astonishment, Muñoz suggests in his reading of Ernst Bloch, 'helps one

\footnotetext{
${ }^{23}$ See Leo Bersani, Homos (Cambridge, MA: Harvard University Press, 1996); Lee Edelman, No Future: Queer Theory and the Death Drive (Durham, NC: Duke University Press, 2004).

${ }^{24}$ Muñoz, Cruising Utopia, pp. 22-23.

25 ibid., p. 25.
} 
surpass the limitations of an alienating presentness and allows one to see a different time and place'. ${ }^{26}$ The lyric subject's fascination with the young man at the crossing is not fearful, nor does it exoticize the soldier. Rather, amidst the alienating and disorienting military imagery, Sandig stages an astonishment that prompts a desire to understand and refuses the distancing rituals between Germans and Soviets.

In 'russenwald', the encounter across time with the soldier guarding the crossing is developed in the final strophe. The image of Soviet soldiers escaping, raiding crops and eating local chickens draws on Soviet soldiers' reputation for criminality. However, this final strophe also stages a fleeting personal encounter between soldiers and local children. Just as military language has been used for its sound and semantic resonances, here military symbols too become tangible in an exchange with the children. The word 'freundschaft' was ubiquitous in East German youth organizations, as the official greeting of the Junge Pioniere and Freie Deutsche Jugend, and the emptiness of this language was satirized even within the GDR. ${ }^{27}$ Yet Sandig reinstates the sincerity of this term to allow a genuine, if transient, moment of exchange between children and soldiers. From line 22 and the description of the encounter, the line lengths become more varied and the rhythm freer, echoing the children's openness to this moment of connection. This final passage underlines the poem's fascination with the troops. Their strangeness to the 'wir' voice sparks not distrust, but a curiosity that extends beyond the moment of exchange, both through the waiting described in the final line and into the present through the act of conjuring up the image in the poem itself. Signs of separation between Soviet troops and the local population remain, especially the 'fallbaum' and the 'zaun', but the childlike tone breaks down this distance and refuses to reject the soldiers as criminals. Rather, the

\footnotetext{
26 ibid., p. 5.

${ }^{27}$ E.g. Zum Teufel mit Harbolla, dir. by Bodo Fürneisen (DEFA, 1989).
} 
meeting is based on astonishment and acceptance, opening the relationship between Germans and Soviets to new meanings.

Sandig's interest in encounters in her depictions of the 'russenwald' can be conceptualized as a form of postcritical poetics. The 'postcritical' has been most prominently developed by Felski, who explores critique as a mood or an affective orientation in literary studies. She unpacks the language of distance, scepticism and suspicion, to demonstrate how critique functions as only one scholarly mood, albeit one that often attains the status of orthodoxy. Instead of the sceptical orientation of critique, Felski calls for attention to the productive and constructive effects of literature. The postcritical perspective, in Felski's writing, is receptive, attentive, and granular in its attention to how a text works. Sandig's writing suggests a form of postcritical writing as a useful extension to Felski's concept. Sandig's poetics are postcritical insofar as she stages an openness to the multiple meanings of the memories and events that her poetry explores. Rather than associate Soviet troops with fear or distrust, her depictions of the 'russenwald' foregrounds the wonder and fascination that coexist with negative responses to the Soviet troops. This openness is productive in the way Felski describes, refusing to relegate German-Soviet relations to the past and pointing instead to the value of openminded interpersonal encounters in the present.

Sandig's works also enact a postcritical poetics in the way they engage the reader or listener. Following Bruno Latour, Felski investigates literary works as "non-human actors' that are not just shaped by reading and reception, but that also act on critics and readers. ${ }^{28}$ For example, she discusses the detective genre as part of the development of

\footnotetext{
${ }^{28}$ Felski, The Limits of Critique, p. 154. See also Bruno Latour, Reassembling the Social: An Introduction to Actor-Network-Theory (Oxford: Oxford University Press, 2005).
} 
sleuth-like critical reading habits, and explores the effects of unreliable modernist narrators on readers' relationships to texts:

The unreliable narrator is not just a formal device but a cultural catalyst, training readers to take on an inquisitorial role and to query the trustworthiness of another's words and, ultimately, perhaps, their own. ${ }^{29}$

In other words, our orientation towards literature is never really distanced or objective, and nor does our analysis act on a passive text. Felski insists that texts co-create our interest and shape our methods, because of our affective response that guides and conditions our understanding. Just as Sandig's poems reimagine the relationship between Germans and Soviet troops, they also draw readers into an interpretive dialogue that mirrors the encounters they depict. For example, the almost hypnotic or sing-song effect of the rhythms in 'russenwald' and the use of slashes to divide meaning up between lines might draw readers or performers into the poem's sound. Moreover, by opening up meaning through telegraphic use of images, the poems encourage a reading that is engaged, dialogical and open to multiple interpretations.

Above all, Sandig's representation of the 'russenwald' is postcritical in its intense awareness of the fraught ethics involved in opening up depictions of Soviet troops to a broader range of interpretations. Felski underlines the distinction between an anticritical rejection of critique, and a postcritical approach that draws on the tools and insights of critique while being aware of the contingency of such an approach and remaining open to other analytical orientations. For all the open-mindedness of 'russenwald' to the Soviet troops, this and other poems are not ignorant of the abuses carried out during the occupation and continued Soviet military presence. The poem's final lines, for example, cast the interpersonal encounter between German children and Soviet soldiers in a decidedly non-utopian light: 'wer das tat, kam lange nicht | wieder. wir warteten

\footnotetext{
${ }^{29}$ Felski, The Limits of Critique, p. 43.
} 
umsonst'. The final line is indented from the left margin, drawing even more attention to it and setting it apart from the preceding lines. The tone of these final sentences is ominous, hinting through the stark, elliptical statements at the punishment and brutality that awaited those who infringed military regulations and sought contact with locals. The openness of the encounter redeems neither the violence of Soviet troops against the civilian populations of Central and Eastern Europe, nor the violence suffered by Soviet soldiers at the hands of their superiors. Rather, this encounter brings with it resonances of violent past encounters, and the spectre of violence in the poem encourages such a reading. Like the poem itself, which sets symbols of military occupation resonating with natural imagery, rhythmic excitement and visual fascination, the openness of the encounter ends with the final line: 'wir warteten umsonst.' The insistence of the repeated 'w' takes on a different, more menacing character, and the poem ends with an expression of futility.

The poem 'gardinen', quoted here in full, presents a more ambivalent, open-ended image of the encounter between children and Soviet troops.

немецкая улица. sechs haben verlegt / einer gab acht, dass keiner mit anpackt / keine mutter mit brot aus dem haus kommt / und grüßt. aber wir

standen am fenster. wir wollten nicht WEG DA. spähten, was los war. auf dieser seite gardinen, auf jener der sommer, die gerte, TEER UND GERÄTE,

sechs rücken. wir zupfen zum zeichen / wir sind immer noch da. los haut mit uns / ab hier, друзья скажиte, wart ihr schon mal / am meer? ${ }^{30}$

The poem is understated, little more than a fleeting impression. Yet the portrayal suggests a fear and brutality that suffuses GDR society, not only in the actions of Soviet soldiers after 1945, but in the abusive military discipline faced by young conscripts. Although the

\footnotetext{
${ }^{30}$ Sandig, Streumen, p. 17.
} 
impression is more ominous than in 'russenwald', the lyric voice in 'gardinen' never addresses this brutality directly. The poem is framed by words in school-level Russian. 'немецкая улица' ('a German street') resembles a stage direction and sets a scene that might have been replicated anywhere in the GDR. The poem centres on six soldiers being redeployed, whose backs are blocking the children's view of the scene, a partial view mirrored in the poem's brevity and its oblique description. The lyric subject's perspective is further obscured by the window and the curtains, so that the poem directly stages a difficulty in understanding, but also a stubborn refusal to avert one's eyes. The voyeurism here is a one-sided exchange, with the curtains allowing the children to peer out, but no evidence of their 'zeichen' being visible from outside. They ignore the exhortation 'WEG DA', and the language of further barked instructions ('los mit euch', 'haut ab', 'weg von hier') is scrambled so that it reads like an imagined invitation for the soldiers to run away with the children: 'los haut mit uns / ab hier'. As with 'russenwald', though, the use of the slash here disrupts any simple reading of this line, ensuring that the cautionary instructions still resonate strongly. The lyric subjects' difficulties understanding are thus turned into a work of reflection, requiring readers and listeners to reflect on the resonances of Sandig's associative language.

By the same token, it is never clear what the 'sechs rücken' are hiding, nor why the children are chastened for looking. The capitalized words 'TEER UND GERÄTE' suggest a group of soldiers repairing or resurfacing a road, with Soviet conscripts used as cheap labour. The isolated image of 'die gerte' in line six hints at the possibility that some form of violence is being concealed. If this is a beating, the poem shrouds it just as the curtains and the soldiers do. Yet the children refuse to look away, twitching the curtains to signal their presence, and the poem ends by undercutting the implicit violence of the scene. The final question, addressed 'друзья скажите' ('tell me, friends'), shows 
the children's lack of comprehension, but also ends the poem on a note of fascination and friendship. Sandig here reinvents a trope once common in East German writing of the sea as a symbol of longing, with the children's imagined question linking their fascination not just to the soldiers' foreignness, signalled in the snatches of Russian, but to their worldliness. Even more clearly than in 'russenwald', a fascination with the soldiers opens up possibilities and hopes, albeit always hidden behind the curtains and cut off from anything more than an imagined interaction with the soldiers.

This short poem powerfully sums up the postcritical force of Sandig's depictions of soldiers. The childlike perspective creates an elliptical impression that encourages an attentive reading that works with the poem. The poem's refusal of understanding stages an act of 'surface reading', with echoes of Stephen Best and Sharon Marcus's engagement with ways of moving beyond the 'suspicion' of critique. ${ }^{31}$ The poem depicts in an intense but oblique way only what the children can observe, and these surface observations reimagine the scenario as an interpersonal encounter that resists the scene's implicit violence. In Felski's terms, the poem stages a 'transformation' of the scene's significance:

a transformation that is not just a matter of intellectual readjustment but one of affective realignment as well (a shift of mood, a sharpened sensation, an unexpected surge of affinity or disorientation). ${ }^{32}$

The poem produces 'an unexpected surge of affinity' not only between the lyric subject and the vulnerable young soldiers, but between readers and the poetic text. By engaging readers or performers in an intense act of reflection, the poem clearly foregrounds a threat of violence, all the more shocking through the contrast with the children's naive perspective that acts as a further curtain to obscure our own understanding.

\footnotetext{
${ }^{31}$ Stephen Best and Sharon Marcus, 'Surface Reading: An Introduction', Representations, 108 (2009), 1-21.

${ }^{32}$ Felski, The Limits of Critique, p. 17.
} 
As in 'russenwald', a blurring of temporal levels is a central feature of 'gardinen' that points to the potential of reimagining memories for the present and future, and demonstrates a further way that transtemporal encounters in Sandig's poetry enact a postcritical poetics. For Felski, different historical periods and temporal levels act on one another in the moment of reading or interpretation, so that texts do more than just reflect their context:

Cross-temporal networks mess up the tidiness of our periodizing schemes; they force us to acknowledge affinity and proximity as well as difference, to grapple with the coevalness and connectedness of past and present. ${ }^{33}$

'gardinen', even more than 'russenwald', brings past and present together. From the midpoint of the poem in line five, it all but dispenses with the past tense of memory and line seven introduces the present tense. Lines seven and eight state explicitly the continued resonance and importance of such memories. The powerful assertion "wir $\mid$ sind immer noch da' moves beyond the present tense of reported speech to suggest that the children's memories and their affinity with the soldiers still remain. The poem shows how these encounters act on people in the present, and its lyric subject remains open to encounters with others even when they are necessarily obscured by time or by a lack of understanding. In contrast with the more fatalistic ending of 'russenwald' and the looming presence of violence in both poems, 'gardinen' ends on a cautiously hopeful note, albeit while remaining in the realm of enigmatic imaginings. The symbol of the sea, the use of Russian to reach out to the soldiers, and the imagined invitation to run away together all gesture to a future based on interpersonal understanding and connectedness. While refusing to allow the past to recede into the distance, Sandig's postcritical style also gestures forwards to an imagined, and possibly illusory, future where the violence of the past can help move beyond aggression to understanding and productive curiosity.

\footnotetext{
33 ibid., p. 159.
} 
Sandig's motifs of openness and interpersonal connections across time are echoed in other contemporary depictions of the Soviet presence in, and later absence from, the territory of the former GDR. Meyer's story 'Glasscherben im Objekt 95' is located more firmly in the present than 'russenwald' or 'gardinen', but shares with Sandig's poetry a persistent elusiveness and blurring of temporal levels. ${ }^{34}$ Meyer's work has most prominently been analysed for his depictions of violence, with substantial interest in his presentation of masculinities. ${ }^{35}$ 'Glasscherben im Objekt 95', though, although set against a backdrop of violence, features a narrator who is reflective, non-violent and even passive. When read in the light of Sandig's writing, the disorienting encounters in Meyer's text appear as a rejection of violence and estrangement in the present and a look to the future potential of encounters based on interpersonal openness.

Meyer's narrator is a night security guard in a building complex on the site of a former Russian barracks, which borders on a home for refugees and asylum seekers. The narrator gestures to his story's disorientating and fragmentary nature, as he repeatedly picks up and discards shards of glass from the ground that act as an externalization of his fragile, fragmented memories that become layered and mixed up. The narrator's job, unchanging in its routine over twenty years, intensifies the sense of temporal blurring in his reflections on the persistent interruptions by his distinctly low-tech walkie-talkie: 'Es [das

\footnotetext{
${ }^{34}$ Meyer, 'Glasscherben': hereafter referenced in the text. Mary Cosgrove investigates temporality in Meyer's earlier work from a contrasting perspective in 'The Temporality of Boredom in the Age of Acceleration: The Car Crash in Contemporary German Literature', in Time in German Literature and Culture, 1900-2015: Between Slowness and Acceleration ed. by Anne Fuchs and J. J. Long (Basingstoke: Palgrave Macmillan, 2016), pp. 204-17.

${ }^{35}$ E.g. Frauke Matthes, 'Clemens Meyer, Als wir träumten: Fighting "Like a Man” in Leipzig’s East', in Emerging German-Language Novelists of the Twenty-First Century, ed. by Lyn Marven and Stuart Taberner (Rochester, NY: Camden House, 2011), pp. 89-104.
} 
Funkgerät] sprach mit uns durch Zeiten und Räume, als ich sie wiedersah an diesem Abend im Objekt 95.' (p. 12) When he sees 'sie', a beautiful young woman in a window, he is transported into memories of a young woman, Marika, whom he met twenty years earlier. This memory initiates a disorientating superimposition of his encounters with the two women, and a blurring of the former barracks with the new building in its place. Unlike Sandig's poems, Meyer's narrative depicts only the changes after the Soviet withdrawal from Germany, but the two writers share an interest in the layers of history in defunct Soviet spaces. As in 'russenwald', the present space is shown as a composite of layers of memory centred around interpersonal encounters across national and linguistic boundaries.

The narrator's encounter with Marika exerts a powerful force on his present, interrupting his routine of patrolling 'Objekt 95'. Marika is never developed as a character, and even her name may be imagined by the narrator: he never describes her introducing herself or uttering her own name. The narrator's initial assumption that Marika is a Russian-German Spätaussiedler draws a link between the Soviet presence in the GDR and immigration from Russia in the 1990s. Marika turns out not to be Russian: "Nicht Russland", sagte sie, "kleines Land, ganz weit. Und Berge. Unser Dorf ... vor den Bergen."' (p. 23) Their countries are linked, though, by the presence and withdrawal of Soviet forces: "“Als die Sowjets bei uns weg, begann Krieg."' (p. 31) The two communicate in fragments of Russian and German, and their confused Russian indicates that it is a foreign language for them both: "'Krasnaja”, sagt sie, aber nicht so laut diesmal, so dass ich es kaum verstehen konnte, "krasiwaja."' (p. 21) The two confuse similar words for 'red' and 'beautiful', but in a way that facilitates rather than impedes comprehension. The language associated with Soviet imperialism in their two countries becomes a means of establishing an interpersonal connection. Just like the encounters between the children and soldiers in 
Sandig's poems, this connection is based on partial understanding and difficulties communicating. Meyer describes a closer physical connection than Sandig, with the narrator kissing and dancing with Marika, and the broader bodily impression made by their encounter indicated in the recurring image of the marks from the metal fence imprinted on their two faces (pp. 20 and 28). This encounter is more intimate than in 'russenwald' or 'gardinen', and leaves a lasting physical as well as mental impression, and yet the disorienting sense that his memories may be illusory closely links Meyer's text to the imagined encounter in 'gardinen' in particular.

The narrator's memories of his encounter with Marika are triggered by a second, more fleeting and possibly even imagined encounter with a woman in a window on the other side of a fence. He initially takes her to be Marika: 'Aber sie war es nicht. Wie konnte sie es auch sein, unverändert und so jung, nach mehr als zwanzig Jahren.' (p. 12) Descriptions of the woman's appearance are repeated throughout the narrative and merge with Marika's appearance. For example, the phrase 'Sie hatte rotbraune, halblange Haare, ihre Haut war sehr hell' describes the woman in the present first (p. 15) and then Marika in the narrator's flashback (p. 19). Unlike in Sandig's poetry, the tenses here rarely shift: all narrative levels use the preterite and the exact repetition of phrases renders any separation between temporal levels increasingly difficult. These shifts between temporalities disorientate the narrator:

Ich strich über das weiche graue Haar des Belgischen Schäferhundes, der plötzlich wieder ein junger Belgischer Schäferhund war. [...] Aber da war gar kein Hund neben mir, der Hund lag im Wachhäuschen, Objekt 95, und meine Hand strich durch die Luft (p. 18).

As with the shards of glass and the impression of the fence on the narrator's forehead, memory here reasserts itself in tangible and tactile ways. Yet the young woman in the narrator's present is remarkably intangible, even though the sight of her brings back memories of holding and dancing with Marika. They cannot communicate effectively in 
either Russian or German: she responds only with 'ja ne snaju’ (I do not know), 'ja ne panimaju' (I do not understand) and 'ich nicht...' (pp. 34-35) It is unclear whether she even speaks more Russian or German than this, and the Arabic script on the calendar in her room may even suggest that the narrator entirely misinterprets her origins. Her unsettled response to the narrator's questioning makes him leave her and retreat into his memories once again. In remembering Marika, he longs for a return to lost openness and physical intimacy, as his fascination with the young woman in the present remains distanced and does not overcome the difficulties in understanding one another. The present encounter is unsettled by and evokes past experiences, with Meyer's text sharing with Sandig's poetry an interest in how past encounters resonate in the present.

Reading Meyer's story in the light of Sandig's poetry reveals a contrasting approach to a postcritical poetics. Both depict moments of intense fascination, accepting the difficulties in fully understanding others and instead exploring the energy and potential of everyday encounters that nevertheless strive for such understanding. Both present politicized portrayals by setting such intimacies, whether real or imagined, against a background of violence. Meyer does not address the violence of Soviet occupation, but rather presentday violence against immigrants in Germany. A flashing light of a police car repeatedly interrupts the narrator's confused sensations, as young men from what he calls the 'Trabantenstadt' - the tower blocks at the edge of the city - throw stones and glass bottles at the 'Ausländerwohnheim'. Sunk in memories, he first sees only 'Blaulicht, ein paar Einsatzwagen' and slowly decodes the image of young men throwing stones: 'was machten sie da, es sah aus, als würden sie turnen, sich verrenken, nächtliche Turner, aber dann hörte ich das Krachen, als einer der Pflastersteine an die Fassade des AW donnerte’ (pp. 28-29). The narrator's incomprehension and passivity continue, and the story ends with him puzzling over where the refugees are being taken as they are bundled into vans. 
The fatalism of this ending, with the anti-immigrant violence and the narrator's frustrated desire for a renewed encounter with Marika, recalls the futility at the end of 'russenwald'. The intrusion of the political struggles of the present into the narrator's memories, though, enacts the engaged postcritical approach advocated by Felski.

Felski is never specific about the ways that a postcritical approach can be more political than an anticritical approach, and Sandig and Meyer present contrasting means of achieving such a politicized approach in postcritical writing. 'russenwald', 'gardinen' and 'Glasscherben im Objekt 95' place a background of violence in the past or present in contrast with often illusory encounters. Meyer presents a narrator so tangled in memories that he is unable to turn his fascination into anything active or productive; there is little of the quiet, everyday defiance of 'gardinen' or the persistent, if futile, waiting in 'russenwald'. Yet like Sandig's open and enigmatic poetry, Meyer's disorienting narrative, and the close attention required to discern its entwined temporal levels, encourage an engaged reading that sees the recurring violence in the text's layers and the potential for everyday interpersonal encounters to model a desired future on a small scale.

The fatalism in Meyer's story and in Sandig's poem 'russenwald', and the violence in all three texts discussed here, seem to jar with the hopefulness of the fleeting encounters presented by both writers. The texts create these encounters as microcosms of intimacy and astonishment, but without exoticizing or excluding others through this fascination. The present in all three texts is repeatedly troubled by fleeting past moments that never attained the imagined potential they were invested with by the lyric subject or the narrator. Muñoz's work offers a means of reinterpreting the apparent failure of these real and imagined encounters in past and present. For Muñoz, queerness is always utopian in its longing for change and its rejection of oppressive societal and epistemological structures in the present. He reads Frank O’Hara’s 'Having a Coke with You' (1960) as 'signif[ying] 
a vast lifeworld of queer relationality, an encrypted sociality, and a utopian potentiality'. ${ }^{36}$ For Muñoz, O'Hara's poem and Warhol's Coke Bottle (1962) 'detect something else in the object of a Coke bottle and in the act of drinking a Coke with someone. [...] Both queer cultural workers are able to detect an opening and indeterminacy in what for many people is a locked-down dead commodity. ${ }^{37}$ Muñoz finds queer potential in Warhol's and O'Hara's search for hope, energy and interpersonal connection amidst the commodification and deadness of a present that, for most queers in the pre-Stonewall age, was indeed dystopian. Sandig's and Meyer's writing is not queer in any usual sense, but they model a similar interest in the fascination and potential that can exist in everyday interactions amidst a present that is often violent or alienating. There is little that is conventionally utopian in their writing, and yet in Muñoz's understanding, utopia is about fleeting, quotidian moments of openness that expose the imperfections of the past and refuse a complacent acceptance of the present. While 'russenwald' and 'Glasscherben im Objekt 95' leave the reader with a sense of futility and fatalism, 'gardinen' exemplifies most clearly the hope and possibility of Muñoz's work.

Above all, the postcritical act of reading encouraged by these works models a way of projecting such encounters into the future. Despite the futility at the end of 'russenwald' and 'Glasscherben im Objekt 95' and the retreat into imagination in 'gardinen', the encounters in these texts are the most prominent elements in both writers' depictions of abandoned Soviet military spaces. The disorientating use of temporal levels in these texts encourages a postcritical reading as set out by Felski, with a close attention and receptivity to the complex cross-temporal resonances of a text and an awareness of the work performed in the act of reading. Whilst Felski describes how detective novels and

\footnotetext{
${ }^{36}$ Muñoz, Cruising Utopia, p. 6.

37 ibid., p. 9.
} 
unreliable narrators have trained readers and scholars in a style of suspicious critique, Sandig's writing models and encourages a productive fascination that finds wonder and potential in moments of interpersonal connection, a strategy that illuminates an analysis of Meyer's work too. Such potential is particularly evident in the complex resonances of Sandig's words and rhythms, and the wide-eyed fascination she stages through the construction of children as lyric subjects. These strategies allow the poems to present interpersonal encounters not as an escape or distraction from violence and imperialism, but rather as politicized everyday moments within a violent past that gesture to more ethical relations in an imagined future. The passivity and disinterest of Meyer's narrator appears to contrast markedly with the fascination of Sandig's lyric subjects. Yet, viewed in the light of Sandig's work, Meyer's writing suggests an alternative way in which writing can encourage an engaged postcritical approach in the act of reading. The potential of the cross-temporal encounters in these texts may remain unrealized, illusory or imagined, but to the extent that Sandig's and Meyer's postcritical poetics use these quotidian moments to interrupt or disrupt an imperfect present, they suggest concrete ways that Felski's postcritical project can take literary form.

Tom Smith is Lecturer in German at the University of St Andrews. His research focuses on East German and contemporary literature and film, with an emphasis on gender and queer studies. He has published on masculinity and queerness in East German film and literature and in contemporary German fiction and life writing. He is currently preparing a monograph on masculinities in depictions of the East German military in literature and film since the 1960s. 